VITAL

VOICES

Issues That Impact

Oregon Adults

Age 45 and Older,

December 2020

Issues of Importance to Oregon Adults Age 45 and Older

\section{Health Care}

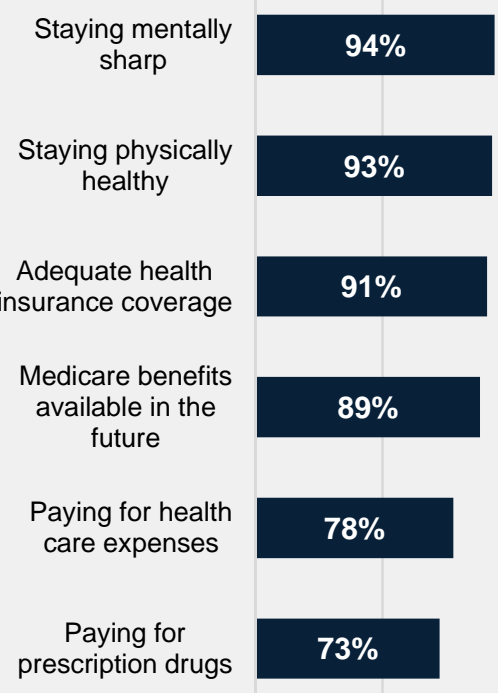

$0 \% \quad 50 \% \quad 100 \%$

\section{Economic/Financial}
Having financial security throughout your life

\section{$91 \%$}

Having enough income or savings to retire

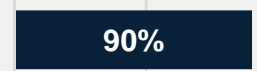

Adequate Social Security benefits

\section{$88 \%$}

Protection against consumer fraud

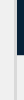

Protection against unfair financial practices

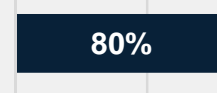

Having online security

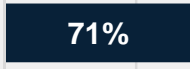

$0 \%$

$50 \%$

\section{Independent Living/ Long-Term Care}

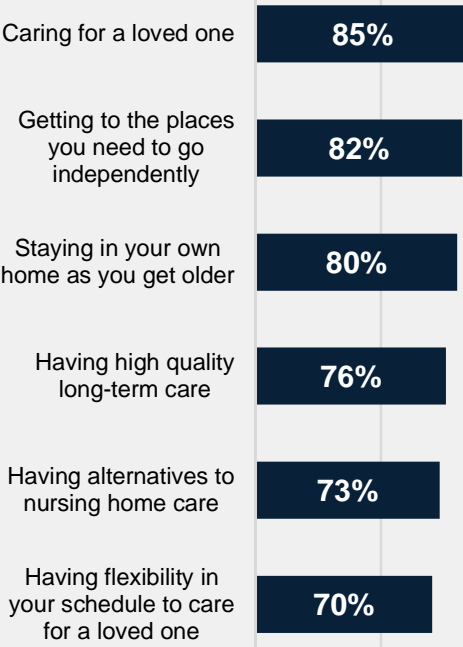
for a loved one

$0 \%$

$50 \%$

$100 \%$

"For the following list of issues, please indicate how important each is to you personally."

\% "extremely important" or "very important" 


\section{Vital Voices: Issues That Impact Oregon Adults Age 45 and Older, December 2020}

Interviews were conducted with 709 residents of Oregon by landline (51\%), cell phone (28\%), and online (22\%) between November 28, 2020 and December 6, 2020.

Age

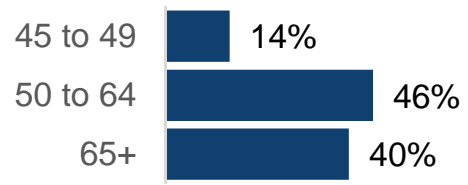

Employment

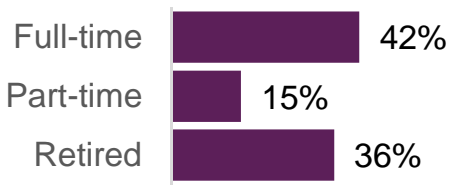

\section{Gender}

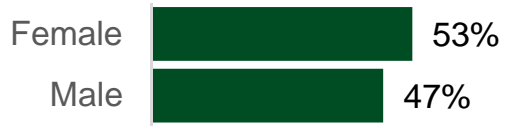

Political Views

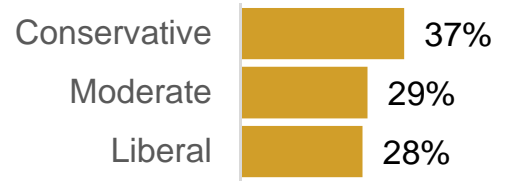

\section{Race/Ethnicity}

White/ Caucasian

Other - Minority

$9 \%$

\section{Education}

Some college or less

4-year college degree

Post-graduate study or degree

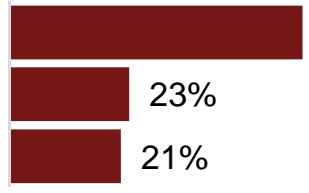

$56 \%$

\section{Marital Status}

Married/ living with partner

Divorced/ separated

Widowed

Never married

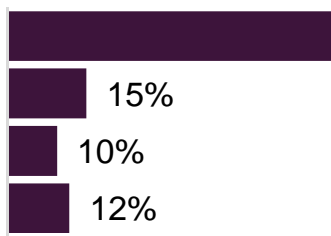

$63 \%$

\section{Annual Household Income}

Less than $\$ 50,000$

$\$ 50,000$ to less than $\$ 100,000$

$\$ 100,000+$

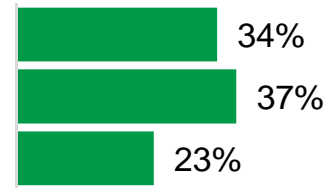

$91 \%$

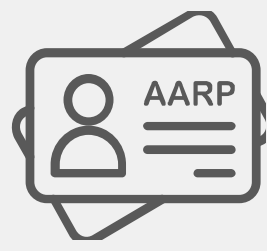

$34 \%$

AARP Member

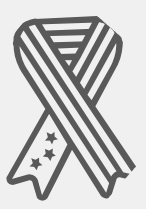

$17 \%$

Veteran 